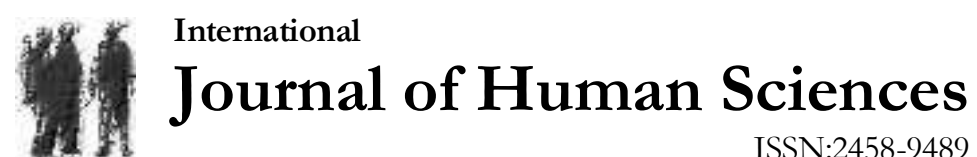

Volume 15 Issue 3 Year: 2018

\section{A content analysis of graduate research on English preparatory programs at universities ${ }^{1}$}

\author{
Mehmet Koçyiğit ${ }^{2}$ \\ Cahit Erdem ${ }^{3}$
}

\begin{abstract}
This study examines master's and doctoral theses on English preparatory classes at tertiary level in Turkey in terms of completion year, thesis type, subject areas, data types, research design, sample groups, problem statements and recommendations. This study is a systematic review of literature and the data was collected through document analysis technique. Content analysis was carried out on the theses selected through criterion sampling method. A total of 82 theses, which were completed by July 2017, were included in the analysis based on inclusion criteria. The analysis reveals significant results as to theses on English preparatory classes at universities. The most frequent subject areas in the theses were identified as learning styles/strategies, motivation/attitude/belief, program evaluation, increasing vocabulary knowledge, reading skills and foreign language anxiety respectively. The majority of the theses rest on quantitative data and employ descriptive research designs. Samples in the theses mostly consist of students while few of them address instructors. The most frequent themes in problem statements include inadequacy, importance and failure while the most frequent recommendations are about motivation and anxiety, and in-service training. This study has the potential to guide future research by putting forth research trends in graduate research on English preparatory classes at tertiary level.
\end{abstract}

Keywords: English preparatory classes; graduate research; theses; content analysis.

\section{Introduction}

Learning a foreign language has many benefits such as being open towards the innovations and improvements, being able to follow publications and news by media tools and travelling to foreign countries more easily as well as getting a better job, a higher salary and social status (Oktay, 2015). Due to these reasons, people across the world invest their efforts to learn a foreign language. As for Turkey, learning and teaching practices regarding foreign language mostly rest on English. In fact, foreign language has been synonymous with English in Turkey for more than half a century (Özmen, Cephe \& Kınk, 2016). The fact that English is the most prestigious foreign language in Turkey stems from the policies of governments in Turkey to spread and enhance learning and

\footnotetext{
1 This study was first presented at I. International Education Research and Teacher Education Congress, 14-16 September 2017, Uşak, Turkey.

2 Asst. Prof. Dr. Faculty of Education, Department of Educational Sciences, Afyon Kocatepe University, mkocyigit@aku.edu.tr

3 Ph.D., Instructor, School of Foreign Languages, Department of Foreign Languages, Afyon Kocatepe University, cerdem@aku.edu.tr
} 
Koçyiğit, M., \& Erdem, C. (2018). A content analysis of graduate research on English preparatory programs at universities. Journal of Human Sciences, 15(3), 1466-1480. doi:10.14687/jhs.v15i3.5414

teaching of English (Sarıçoban \& Sarıçoban, 2012). Therefore, teaching of English is practiced in all levels of education in Turkey as a required subject, both in private and state Institutes.

Alptekin \& Tatar (2011) argue that Turkish people's exposure to Western languages dates back to $18^{\text {th }}$ century and substantive reforms took place in foreign language teaching and learning with the foundation of Republic of Turkey. They also suggest that sending tertiary-level students to Western countries, foundation of education colleges (Anatolian high schools) with dual language instruction, English-medium state and private universities, parallel English medium programs in Turkish medium universities, development of English as a lingua franca and financial incentives offered by private and public sectors in Turkey for employees with a satisfactory level of English have all paved the way for the predominance of English in Turkey. In addition, English serves as an instrument for political, economic and cultural relations with the West (İnal, Özdemir, Kiray \& Oral, 2016).

Despite the given dominance and significance of English in Turkey, the quality of foreign language education is highly discussed, criticized and researched (Cesur, 2008; Demir, 2012; Evcim, 2008; Kilıç, 1992). Oktay (2015, p.584) lines up the problems in foreign language teaching and learning which are: (1) Turkey's policy in foreign language teaching is not sufficient enough, (2) foreign language courses are generally called "teacher-centered", (3) too much emphasis is given in grammar, (4) students are not spending enough time for language learning, (5) classes are too crowded, (6) language teaching is not starting early enough and environment for language teaching is not sufficient enough, (7) there is not enough practice, (8) no questions are asked in the university entrance exams in a foreign language, (9) students motivation to learn the language is not enough, (10) homework is not helpful with the language learning and students' active participation in foreign language courses is insufficient.

In addition to elementary and secondary schooling, higher education Institutes in Turkey provide English language education because of the ineffective education in former levels. Most of the language education provided in elementary and secondary schools at a low proficiency level is expected to result in merely 'educational learning' which only leads to the increase of knowledge but students cannot use this knowledge to interact and participate in the new language (Atar, 2014, p.20) Preparatory classes, schools of foreign languages and departments of foreign languages affiliated to rectorates serve for this need (Özkanal, 2009). Particularly preparatory classes for teaching English are common in tertiary levels. Procedures and principles for the functioning of these classes have continuously been changed and the final arrangement was carried out by Council of Higher Education with a regulation published in the official gazette in 2016.

This regulation holds that there are two types of preparatory foreign language classes, which are mandatory classes and optional classes. The former addresses the students in the departments which, fully or partially, offer education in English medium. The latter offers foreign language education for students in departments with Turkish medium language. Students in mandatory classes who cannot be successful in two years do not have the right to continue their education. Students in optional classes can move on to their departments even if they are unsuccessful in language education.

The widespread teaching of English and over 50 departments of English language teaching and linguistics in Turkish universities have increased the academic research on this issue (Yağı, Aydın \& Akdemir, 2016). Besides, reasons such as the incongruence between policy objectives and instructional practices (Sarıçoban \& Sarıçoban, 2012), the need for competent English instructors in universities (Özmen, Cephe \& Kınik, 2016) and the inefficiency in gaining the necessary language skills at the targeted levels till the end of higher education (Oktay, 2015) have concentrated research on preparatory English classes. Issues addressed in these studies include duration, nature and medium of instruction, curriculum planning, course book teaching, material design and assessment (Inal et al., 2016).

In order to integrate academic studies to see their mutual contributions, there is a need in examining and comparing research studies periodically (Cohen, Manion \& Morrison, 2005; Selçuk, 
Koçyiğit, M., \& Erdem, C. (2018). A content analysis of graduate research on English preparatory programs at universities. Journal of Human Sciences, 15(3), 1466-1480. doi:10.14687/ihs.v15i3.5414

Palanc1, Kandemir \& Dündar, 2014). These synthesizing studies, in any field, may focus on articles (Solak, 2014; Yağız, Aydın \& Akdemir, 2016), theses (Adıgüzel \& Ergünay, 2012; İnal et al., 2016; Özmen, Cephe \& Kınık, 2016) or studies in certain journals (Eğmir, Erdem \& Koçyiğit, 2017) though some studies also examine articles, proceedings and theses (Alptekin \& Tatar, 2011). With respect to ELT and applied linguistics, research trends in articles and theses are examined by researchers around the world (Motha, 2009; Woravut, 2012). In spite of this, there are a few review studies in Turkish context that deal with the research trends in the field of English language learning and teaching. Despite the considerable number of research studies in this field, systematic review of them are quite rare in Turkish scientific context (Solak, 2014; Yağı, Aydın \& Akdemir, 2016) Accordingly, more studies in specific fields of ELT are needed to be reviewed to get a mutual conclusion from the studies carried out independently and guidance for future research. The review studies on teaching and learning of English are explained below.

Graduate research on teaching and learning of English in Turkey was examined by Özmen, Cephe \& Kınik (2016) and İnal et al. (2016). Özmen, Cephe \& Kınık (2016) examined 137 doctoral research studies on English language teaching in Turkey between 2010 and 2014. The major subject areas of the 137 theses are teaching English as a foreign language, foreign language teacher education and second language acquisition. Teaching English as a foreign language theme included the sub-areas of language skills, language components, curricular studies, testing, learner and teacher variables, document analysis \& language use, world Englishes, technology, young learners, intercultural communication, multiple intelligences, and other issues, foreign language teacher education theme included sub-areas of preservice teacher education and in-service training, and second language acquisition theme included sub-areas of acquisition of morphosyntax, acquisition of lexemes, error analysis and focus on form. Inal et al. (2016) reviewed doctoral research on English language teaching and learning between 2009 and 2013 at Turkish universities. They categorized the 25 theses into four groups according to their research focus: (1) instructional variables and designs, (2) learners, (3) textbooks, (4) program development and evaluation.

In addition to graduate research, articles on teaching and learning of English in Turkish context were examined by Solak (2014) and Yağız, Aydın \& Akdemir (2016). Solak (2014) examined 189 research papers on foreign language teaching in Turkish context published between 2009-2013 in SSCI and Ulakbim databases. The variables were year, authors, language of the paper, journal index, topic of the paper, research design, data collection tools, sample, sample size and data analysis method. The most frequently studied topics were found to be teaching, learning, concept analysis, educational technology, teacher training, attitudes, curriculum studies, development and adaptation of scales and tests, development of teaching materials and other topics. Yağız, Aydın \& Akdemir (2016) examined 274 research articles published in Turkey between 2005 and 2015 in the field of English language teaching and learning as a foreign language. They found out that language learning and teaching is the most common focus in the studies and quantitative research designs with descriptive tools and analysis procedures are preferred more.

Finally, Alptekin \& Tatar (2011) reviewed nearly 130 articles, conference proceedings and doctoral theses on applied linguistics and foreign language education for the period of 2005-2009 in Turkey. The main areas of the studies were foreign language teaching and teachers, foreign language learning and learners, foreign language teacher education, the four language skills, measurement and evaluation, and the relationship between language and culture.

These review studies are on teaching and learning English as a foreign language in general. İnal et al (2016) and Özmen, Cephe \& Kinık's (2016) studies are on graduate research while Solak (2014) and Yağız, Aydın \& Akdemir's (2016) studies are on articles. Besides, Alptekin \& Tatar's study is on articles, conference proceedings and graduate research. They yield rich data as to ELT field. For instance, they reveal that the research on ELT mostly focus on teaching and learning, learner characteristics, four language skills, teacher training, evaluation, textbooks/materials, curriculum development and educational technology. Though these review studies point to the general trends in ELT field, studies analyzing more specific sectors of ELT are also needed as they 
Koçyiğit, M., \& Erdem, C. (2018). A content analysis of graduate research on English preparatory programs at universities. Journal of Human Sciences, 15(3), 1466-1480. doi:10.14687/jhs.v15i3.5414

would provide concrete conclusions and recommendations about that sector. There aren't any studies reviewing the research on English preparatory classes at tertiary level, which account for the majority of foreign language teaching in universities.

Given the significance of preparatory English classes in universities in Turkey, the number of students attending these classes and the accumulation of research studies particularly theses on these classes require an in-depth review. In addition, the above-cited review studies are limited to short time spans of research as they include the whole field. Analyzing specific factors of a field within a long-time span would provide the longitudinal trends. The first graduate research on English preparatory classes was finished in 1992. This analysis may help researchers see the research trends in English preparatory classes at tertiary level and help them base their future research on these findings. Therefore, this study aims to carry out an analysis of master's and doctoral theses on English preparatory classes at universities in Turkey.

\section{Purpose of the Study}

The purpose of this study is to analyse the master's and doctoral theses about English preparatory classes at tertiary level in Turkey in terms of thesis type and thus put forth research trends to guide future research.

\subsection{Research Questions}

RQ1: What is the distribution of theses in terms of thesis type and year?

RQ2: What is the distribution of theses in terms of the subject areas of the studies?

RQ3: What is the distribution of theses in terms of data types?

RQ4: What is the distribution of theses in terms of research design?

RQ5: What is the distribution of theses in terms of participants?

RQ6: What is the distribution of theses in terms of problem statements?

RQ7: What is the distribution of theses in terms of recommendations?

\section{Method}

This study is a systematic review of the literature. The data was collected through document analysis technique. Document analysis includes analysis of written documents such as official publications, reports, records, open ended answers to surveys (Patton, 2002), which is dissertation in this study. Content analysis was carried out on the data obtained. In content analysis, it is aimed to describe the characteristics of a document by counting occurrences of themes, words or phrases within the documents (Bloor \& Wood, 2006, p.58). The theses were grouped under themes of subject areas according to their titles, keywords and the topics studied. While coding and categorising the data, constant comparison technique was used for consistency. All the theses analysed in this study can be accessed online from the thesis centre of the Higher Education Council (tez.yok.gov.tr), which is worth mentioning for the sake of the validity of the study. 
Koçyiğit, M., \& Erdem, C. (2018). A content analysis of graduate research on English preparatory programs at universities. Journal of Human Sciences, 15(3), 1466-1480. doi:10.14687/jhs.v15i3.5414

\subsection{Sample}

A total of 82 theses ${ }^{4}$ comprise the sample of this study, which were selected through criterion sampling method. In the sampling process, some inclusion criteria were used. The sample was obtained from the thesis centre of the Higher Education Council using the keywords "preparatory class (hazırlik sinifi)" and "preparatory programme (hazırlik programi)". After the search was completed, the analyses were carried on the theses which were open to access by the authors. Theses about the prep classes of other languages than English; theses about prep classes in secondary education; and theses about different preparatory programmes (e.g. marriage preparatory courses and so on) were excluded. As of July 2017, there were 82 theses compatible with the inclusion criteria which were taken as the sample of this study.

\section{Findings}

\subsection{The type and year of theses}

Of the theses, $69(84.1 \%)$ were master's theses and $13(15.9 \%)$ were doctoral theses. The distribution of the theses with respect to completion year can be seen in Table 1.

Table 1. Distribution of theses in terms of year

\begin{tabular}{lll}
\hline Year & $f$ & $\%$ \\
1992 & 1 & 1,2 \\
1994 & 1 & 1,2 \\
1996 & 1 & 1,2 \\
1998 & 1 & 1,2 \\
1999 & 1 & 1,2 \\
2001 & 1 & 1,2 \\
2004 & 4 & 4,9 \\
2005 & 1 & 1,2 \\
2006 & 2 & 2,4 \\
2007 & 3 & 3,7 \\
2008 & 8 & 9,8 \\
2009 & 4 & 4,9 \\
2010 & 5 & 6,1 \\
2011 & 8 & 9,8 \\
2012 & 9 & 11 \\
2013 & 7 & 8,5 \\
2014 & 8 & 9,8 \\
2015 & 6 & 7,3 \\
2016 & 7 & 8,5 \\
2017 & 4 & 4,9 \\
Total & 82 & 100,0 \\
\hline & &
\end{tabular}

\footnotetext{
${ }^{4}$ Akpur, 2015; Alıcı, 2004; Altaş, 2012; Altıner, 2008; Arın, 2010; Ataman, 2017; Ateş Özdemir, 2014; Aydemir, 2011; Aydemir, 2013; Aydın, 1998; Ayhan, 2014; Balabakgil, 2016; Balcı, 2017; Balkul, 2010; Baylan, 2007; Bayram, 2011; Bora, 2013; Cengizhan, 2016; Cesur, 2008; Cincioğlu, 2012; Çekirdek, 2014; Çelik, 2015; Çetinkaya, 2017; Çevikbaş, 2016; Dağlığlu, 2004; Daylan, 2001; Demir, 2012; Demirkol, 2009; Derince, 2016; Doğan, 2016; Efe, 1996; Erakman, 2015; Erarslan, 2011; Erkol, 2011; Ertan, 2008; Evcim, 2008; Felek Başaran, 2011; Gülsoy, 2011; Gültekin Çakar, 2009; Gündüz, 2015; Güneş, 2004; Güntürkün, 2007; Gürata, 2008; Hiçyılmaz, 2006; İleri, 2013; Kar, 2014; Karabey, 2011; Karabıyık, 2008; Karagöl, 2015; Karakılıç, 2014; Kaya, 2014; Keşmer, 2007; Kılıç, 1992; Koçer, 2012; Korkmaz, 2014; Köse, 2012; Mede, 2012; Oğuz, 2017; Ok, 2005; Önkuzu, 2013; Özaydınlı, 1994; Özdoğru, 2008; Özkanal, 2009; Özkardeş, 2011; Öztürk, 2010; Padem, 2012; Pulat, 2010; Sarar, 2008; Sakrak, 2009; Şanlı, 2016; Şen, 2012; Tatış, 2010; Temir, 2015; Toker, 1999; Tokuç, 2014; Uludağ, 2013; Uzun, 2013; Yalçın, 2016; Yıldız, 2013; Yılmaz, 2004; Yılmaz Yakışık, 2012; Yördem, 2016
} 
It can be seen from Table 1 that the highest number of theses was completed in the period of 2011-2014. The year 2008 stands out exceptionally out of this period with a number of eight studies. It can be inferred that the studies about preparatory classes at universities in Turkey started to boom in the year 2008 with an exceptional decline in the year 2009. In July 2017, there were already four theses which is an indicator of the interest continuing about the topic.

\subsection{Subject areas of theses}

The theses about the preparatory classes in Turkey were grouped under themes of subject areas according to the topic they focused on, the titles of the theses and keywords of their abstracts. The distribution of theses with respect to subject areas is provided in Table 2.

Table 2. Subject areas of theses

\begin{tabular}{lll}
\hline Subject areas & $f$ & $\%$ \\
\hline Learning styles/strategies & 10 & 12.2 \\
Motivation/attitude/belief & 8 & 9,8 \\
Program evaluation & 7 & 8,5 \\
Increasing vocabulary knowledge & 5 & 6,1 \\
Reading skills & 5 & 6,1 \\
Foreign language anxiety & 5 & 6,1 \\
Needs analysis & 4 & 4,9 \\
CALL & 3 & 3,7 \\
Meta-cognitive strategies & 3 & 3,7 \\
Writing skills & 3 & 3,7 \\
Grammar mistakes & 2 & 2,4 \\
Listening comprehension skills & 2 & 2,4 \\
Opinions & 2 & 2,4 \\
Speaking skills & 2 & 2,4 \\
Native, non-native teacher & 2 & 2,4 \\
Causal attributions & 2 & 2,4 \\
Student autonomy & 2 & 2,4 \\
Curriculum design/evaluation & 2 & 2,4 \\
Use of mother tongue & 1 & 1,2 \\
Course book review & 1 & 1,2 \\
Course book adaptation & 1 \\
Language competence and alignment to university & 1 & 1,2 \\
Critical literacy & 1 & 1,2 \\
Blended learning & 1 & 1,2 \\
Integration of the target culture to classroom & 1 & 1,2 \\
Achievement of English & 1 & 1,2 \\
Syllabus design & 1 & 1,2 \\
Attitudes towards homework & 1 & 1,2 \\
Student burnout & 1 & 1,2 \\
Problems in assessment & 1 & 1,2 \\
Performance management system & 1,2 \\
Total & 1,2 \\
& 100 \\
\hline
\end{tabular}


Koçyiğit, M., \& Erdem, C. (2018). A content analysis of graduate research on English preparatory programs at universities. Journal of Human Sciences, 15(3), 1466-1480. doi:10.14687/ihs.v15i3.5414

As Table 2 reveals, 82 theses were grouped under 32 themes of subject areas ranging from learning styles to performance management systems. The most studied three subject areas were learning styles/strategies ( $\mathrm{f}=10,12.2 \%)$, motivation/attitude/belief $(\mathrm{f}=8,9.8 \%)$ and program evaluation $(\mathrm{f}=7,8.5 \%)$ while only one thesis each was completed in 14 themes.

\subsection{The types of data in theses}

The distribution of the theses according to the types of the data collected is given in Table 3 .

Table 3. Distribution of theses in terms of the data types

\begin{tabular}{lll}
\hline Data types & $f$ & $\%$ \\
\hline Quantitative & 56 & 68,3 \\
Mixed & 19 & 23,2 \\
Qualitative & 7 & 8,5 \\
Total & 82 & 100,0 \\
\hline
\end{tabular}

It is observed in Table 3 that the majority of the theses collected quantitative data ( $f=56$, $68.3 \%) .19$ of the theses collected mixed data $(23.2 \%)$ and in seven theses qualitative data were collected (8.5\%).

\subsection{The research designs of theses}

The theses were grouped according to the research design employed. The distribution of the theses in this respect can be seen in Table 4.

Table 4. Distribution of theses in terms of research design

\begin{tabular}{lll}
\hline Research design & $f$ & $\frac{f}{79,3}$ \\
\hline Descriptive & 65 & 19,5 \\
Quasi-experimental & 16 & 1,2 \\
Causal comparison & 1 & 100,0 \\
Total & 82 & \\
\hline
\end{tabular}

Most of the studies ( $\mathrm{f}=6576.8 \%$ ) used a descriptive research design. 16 of the theses are quasi-experimental (19.5\%), 2 are curriculum development studies $(2.4 \%)$ and one $(1.2 \%)$ is a causal comparative study.

\subsection{The participants in the theses}

In the theses about English preparatory classes, a total of 19.044 students and 792 academics comprised the samples. The distribution of the theses with respect to the sample groups addressed can be seen in Table 5 .

Table 5. Distribution of theses in terms of sample groups

\begin{tabular}{lll}
\hline Sample & $f$ & $\%$ \\
\cline { 1 - 3 } Student & 53 & 64,6 \\
Student/instructor & 23 & 28,0 \\
Instructor & 6 & 7,3 \\
Total & 82 & 100 \\
\hline
\end{tabular}

53 of the theses $(64.6 \%)$ have samples consisting of students, 23 of the studies have mixed samples of students and instructors together $(28 \%)$, and 6 of the studies have samples consisting of instructors alone $(7.3 \%)$. 
Koçyiğit, M., \& Erdem, C. (2018). A content analysis of graduate research on English preparatory programs at universities. Journal of Human Sciences, 15(3), 1466-1480. doi:10.14687/jhs.v15i3.5414

\subsection{Problem statements in the theses}

In all the 82 studies, 156 problems were stated, 118 of which could be grouped under 7 meaningful themes and 28 sub-themes. The remaining problems were grouped under the category of others. Table 6 lists the themes of problems.

Table 6. Problem statements of theses

\begin{tabular}{|c|c|c|c|}
\hline Themes & $f$ & Sub-themes & $f$ \\
\hline \multirow[t]{5}{*}{ Inadequacy } & 38 & of research about the topic studied & 16 \\
\hline & & of teaching vocabulary & 6 \\
\hline & & of the curriculum & 3 \\
\hline & & of motivation & 3 \\
\hline & & other issues & 10 \\
\hline \multirow[t]{7}{*}{ Importance } & 33 & of teaching English & 6 \\
\hline & & of individual differences & 5 \\
\hline & & of teaching learning process & 5 \\
\hline & & of motivation-attitude & 4 \\
\hline & & of affective characteristics & 3 \\
\hline & & of thinking strategies & 2 \\
\hline & & of other issues & 8 \\
\hline \multirow{3}{*}{$\begin{array}{l}\text { Ineffectiveness / } \\
\text { failure }\end{array}$} & 18 & General failure in language teaching & 12 \\
\hline & & Failure in exams & 3 \\
\hline & & Other issues & 3 \\
\hline \multirow[t]{2}{*}{ Needs } & 11 & Of students & 8 \\
\hline & & Various needs & 3 \\
\hline \multirow[t]{6}{*}{ Skills } & 8 & Writing skill & 1 \\
\hline & & Reading skill & 1 \\
\hline & & Speaking skill & 2 \\
\hline & & Listening skill & 1 \\
\hline & & Other skills & 2 \\
\hline & & Four skills & 1 \\
\hline \multirow[t]{3}{*}{ Problems } & 6 & About curriculum & 2 \\
\hline & & Of students & 3 \\
\hline & & Of instructors & 1 \\
\hline \multirow{2}{*}{$\begin{array}{l}\text { Unawareness } \\
\text { about an issue }\end{array}$} & 4 & About students & 3 \\
\hline & & About instructors & 1 \\
\hline Other & 38 & & \\
\hline
\end{tabular}

The most frequent theme of problem statements is inadequacy which consists of statements about inadequacies of research about the topic studied in the literature, teaching vocabulary, curriculum, motivation and other specific issues that could not be categorized. Following inadequacy, the next frequently studied theme is importance. The problem statements in the theses included expressions as to the importance of teaching English, individual differences, teaching-learning process, motivation-attitude and so on. The third theme is ineffectiveness or failures which are about general failure in language teaching or failure in exams. The fourth theme is about the needs which are mostly about students. Skill theme includes issues about four skills collectively or writing, reading, speaking and listening skills individually. The next theme involves problems as to curriculum, students and instructors. Lastly, four theses justified the topic as a result of a lack of knowledge or unawareness about the issue and thereby to obtain information about it. 
Koçyiğit, M., \& Erdem, C. (2018). A content analysis of graduate research on English preparatory programs at universities. Journal of Human Sciences, 15(3), 1466-1480. doi:10.14687/jhs.v15i3.5414

\subsection{Recommendations of the theses}

In 82 theses analysed, there were 275 recommendations excluding implications for further research. The categories of recommendations are provided in Table 7.

Table 7. Recommendations of theses

\begin{tabular}{ll}
\hline Subject & $f$ \\
\hline Regarding motivation and anxiety & 21 \\
In-service training, new courses, briefing & 20 \\
About skills & 15 \\
About curriculum & 13 \\
About ESP & 13 \\
About giving more importance to various & 11 \\
issues & \\
About course/activity books & 11 \\
Regarding raising awareness & 7 \\
Use of L1 & 7 \\
Regarding communicative teaching & 5 \\
Interests, needs, individual differences & 3 \\
Other (couldn't be categorized) & 149 \\
\hline
\end{tabular}

There are various recommendations about various specified subjects and practices and there are ones containing general statements or ones about more than one matter at a time. The recommendations were grouped under categories according to the issues they address and 126 of them were grouped under 11 categories (see table 7). The rest includes individual recommendations in a wide range of issues. The most frequent recommendations are on motivation and anxiety, inservice training, new courses and briefing while the least frequent ones are on interests, needs and individual differences as well as specific recommendations in the category of other.

\section{Discussion and Conclusion}

With the aim of carrying out a content analysis on graduate theses about English preparatory classes at universities in Turkey, this study examined 82 master's and doctoral theses in terms of thesis type and year, subject areas, data type, research design, sample groups, problem statements and recommendations. It was identified in the analysis that 69 master's (84.1\%) and 13 doctoral $(15.9 \%)$ theses were completed and were accessible by July 2017. This high number of graduate research indicates the academic interest in English preparatory classes at tertiary level in Turkey. When the completion years of the theses are analysed, it is seen that the period of 20112014 accommodates condensation of theses with the highest rate of 11\% in 2012 and the number of theses continues to increase at a high rate, as well. This finding is in parallel with articles on ELT, too. Solak (2014) found out that the highest number of articles on ELT was published in 2013 in the period of 2009-2013 and Yağı, Aydın \& Akdemir (2016) report that the highest number of articles were published in 2013, 2011 and 2014 respectively between 2005 and 2015.

The subject areas of 82 theses were grouped and the most frequent themes were identified as learning styles/strategies, motivation/attitude/belief, program evaluation, increasing vocabulary knowledge, reading skills and foreign language anxiety respectively. Similar review studies in the literature grouped research in terms of themes or subject areas in broad categories. For instance, Özmen, Cephe \& Kinik (2016) reviewed doctoral theses on ELT between 2010 and 2014 and found out that the subject areas of theses were teaching English as a foreign language, foreign language teacher education and second language acquisition. The most frequent sub-areas included pre-service teacher education, learner and teacher variables, and language skills respectively. Solak (2014) reviewed articles on foreign language teaching from 2009 to 2013 and found out that the 
Koçyiğit, M., \& Erdem, C. (2018). A content analysis of graduate research on English preparatory programs at universities. Journal of Human Sciences, 15(3), 1466-1480. doi:10.14687/jhs.v15i3.5414

most frequently studied topics include teaching, learning and concept analysis. Furthermore, Yağı, Aydin \& Akdemir (2016) list the most frequently subjects of articles on ELT published between 2005 and 2015 as language learning \& acquisition, language teaching and teacher education respectively. When the categories in this study are considered in a broader manner, it can be suggested that the themes of theses on English preparatory classes at tertiary level are in the same fashion with theses and articles on ELT.

It was identified in the analysis that the majority of the theses rest on quantitative data $(68.3 \%)$. Mixed data $(23.2 \%)$ and qualitative data $(8.5 \%)$ follow it. Besides, more than three-quarters of the theses employed a descriptive research design. The dominance of quantitative methods and data in theses on English preparatory classes at tertiary level coincides with other theses and articles on ELT. Inal et al. (2016) found out that doctoral ELT research from 2009 to 2013 mostly employed quantitative research design. Similarly, Solak (2014) identified that nearly half of the articles on foreign language education from 2009 to 2013 employed quantitative research designs $(48.7 \%)$ while this ratio is $33.9 \%$ for qualitative methods and $17.5 \%$ for mixed methods. While $71.1 \%$ of articles on ELT published between 2005-2015 employed quantitative methods, only 13.5\% used mixed methods and 9.5\% used qualitative methods (Yağız, Aydın \& Akdemir, 2016). However, Özmen, Cephe \& Kınık (2016) identified that, of the doctoral ELT theses between 2010 and 2014, 71\% used mixed methods, 24\% used quantitative methods while only 5\% used qualitative methods. The high ratio of mixed methods is an interesting finding; however, they also reported that studies with mixed method mostly relied on quantitative data. The findings of this study and other review studies on ELT reveal that there is need for studies with more qualitative data to get a richer understanding of the issues in the field.

Most of the theses on English preparatory classes at tertiary level in Turkey (64.6\%) have samples consisting of students while few studies have samples consisting of instructors alone (7.3\%). This case is also valid for articles. Solak (2014) found out in his review of articles on foreign language education from 2009 to 2013 that while mostly students from elementary to post graduate level constitute the samples in papers, teachers/instructors make up only $8.5 \%$. Similarly, the ratio of teachers and academics in the samples of articles on ELT published between 2005-2015 is 21\% (Yağız, Aydın \& Akdemir, 2016). These findings unearth the need to address the experiences of instructors who are one of the most important stakeholders in foreign language learning and teaching process.

The problem statements which form the bases for the studies and give out the motives of the researchers, indeed, show so much similarities or contiguities that 118 of the total 156 could be grouped under seven categories. Inadequacy, ineffectiveness and importance are the most recurring motives for the study. A total of 275 recommendations were made in the theses, 20 of which are about in-service training or putting new courses in faculty curricula for teacher education. Two issues come forth as a result of these recommendations. The first is, all the training programmes or new courses would have their own needs of resources, curriculum, planning and books and would have their own problems similar to the ones of ELT or preparatory classes. It sounds like a solution causing new similar problems; however, none of the recommendations included any idea in terms of this aspect. The second twister is caused by the questions of how, where and when the recommended courses or training programmes can be applied, who the teachers would be and which resources would be used.

To conclude, this study analysed masters' and doctoral theses on English preparatory classes at tertiary level in Turkey and reached significant findings as to the subject areas of the studies, data type, research design, sample groups, problem statements and recommendations. English preparatory classes are an important part of foreign language learning and teaching experiences. Such that, 26\% of the doctoral ELT theses between 2010-2014 are about English preparatory programs of the universities (Özmen, Cephe \& Kınık, 2016) and there is a need for more research. However, the future studies should be guided based on the previous studies. This study serves for this need and provides a general picture of the literature of graduate research on English 
Koçyiğit, M., \& Erdem, C. (2018). A content analysis of graduate research on English preparatory programs at universities. Journal of Human Sciences, 15(3), 1466-1480. doi:10.14687/jhs.v15i3.5414

preparatory classes of universities by putting forth the research trends in the field. While determining new subject areas for research and designing studies, this study could be taken into consideration to prevent repetition.

\section{REFERENCES}

Adıgüzel, O. C. \& Ergünay, O. (2012). An investigation of dissertations on values in Turkey from the perspective of educational science and teacher training. Electronic Journal of Social Sciences, 11(41), $18-33$.

Akpur, U. (2015). Ingilizce haz̨rlk program ögrencilerinin akademik motivasyon, kayg ve tutumlar ile akademik başarları arasindaki ilişkiler örüntüsü. Unpublished Doctoral Thesis, Yıldız Technical University, Institute of Social Sciences.

Alıcı, S.S. (2004). Yaldı ₹ Teknik üniversitesi yabancı diller yükesekokulu bažrllk simfı ögrencilerinin kendilerine sağlanan ögretimin nitelï̈ine ilişkin görüsler. Unpublished Master Thesis, Yıldız Technical University, Institute of Social Sciences.

Alptekin, C. \& Tatar, S. (2011). Research on foreign language teaching and learning in Turkey (20052009). Language Teaching, 44(3), 328-353.

Altaş, T. (2012). An analysis of preparatory school students' needs from a constructivist perspective with a focus on bottom-up learning. Unpublished Doctoral Thesis, Gazi University, Institute of Educational Sciences.

Altıner, S. (2008). The attitudes of preparatory students in abant izzet baysal university, turkey and Sussex university, UK towards pronunciation practice in english courses. Unpublished Master Thesis, Abant Izzet Baysal University, Institute of Social Sciences.

Arin, N. (2010). From prep class to first year: an investigation into the transitional effects of a one-year English preparatory continuum on language proficiency and university adjustgments. Unpublished Master Thesis, Çukurova University, Institute of Social Sciences.

Ataman, O. (2017). The relationship between preparatory class students' motivation and attitude towards learning English and their preparatory class acbievement scores. Unpublished Master Thesis, Sakarya University, Institute of Educational Sciences.

Atar, C. (2014). Do Turkish bilinguals of English process Turkish predictive conditionals different than Turkish monolinguals? Annual Review of Education, Communication and Language Sciences, 11, 15-34.

Ateş Özdemir, H. (2014). An empirical study on the contribution of mnemonic narrative chain method to vocabulary learning and retention of English preparatory students. Unpublished Master Thesis, Necmettin Erbakan University, Institute of Educational Sciences.

Aydemir, E. (2013). Perceptions of state and private university language preparatory program instructors related to integrating target culture in an EFL classroom. Unpublished Master Thesis, Yeditepe University, Institute of Educational Sciences.

Aydemir, O. (2011). A study on the changes in the foreign language anxiety levels experienced by the students of the preparatory school at gazi university during an academic year. Unpublished Master Thesis, Gazi University, Institute of Educational Sciences.

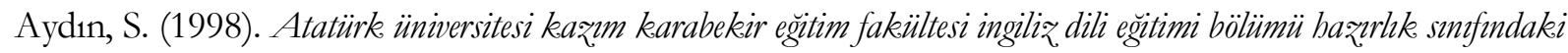
test uygulamalarmda karşzlaşzlan sorunlar ve ģöəümler. Unpublished Master Thesis, Atatürk University, Institute of Social Sciences.

Ayhan, H. (2014). The effect of extensive reading on the development of reading and writing skills of English preparatory class students. Unpublished Master Thesis, Anadolu University, Institute of Educational Sciences.

Balabakgil, B. (2016). The use of L1 as a teaching strategy by native and non-native efl instructors at a language preparatory program in Turkey. Unpublished Master Thesis, Bahçeşehir University, Institute of Educational Sciences.

Balc1, E. (2017). Perceptions on blended learning: a study on student and instructor experiences in an English preparatory program. Unpublished Master Thesis, Pamukkale University, Institute of Educational Sciences. 
Koçyiğit, M., \& Erdem, C. (2018). A content analysis of graduate research on English preparatory programs at universities. Journal of Human Sciences, 15(3), 1466-1480. doi:10.14687/ihs.v15i3.5414

Balkul, H. I. (2010). The attitudes of the learners in intensive English programme at sakarya university towards computer assisted language learning. Unpublished Master Thesis, Uludağ University, Institute of Social Sciences.

Baylan, S. (2007). University students' and their teachers' perceptions and expectations of learner autonomy in efl prep classes. Unpublished Master Thesis, Marmara University, Institute of Educational Sciences.

Bayram, İ. (2011). TOBB ekonomi ve teknoloji üniversitesi yabanc diller bölümü ingilizce bąırlık programmın ögretmen ve ögrenci görüslerine göre değerlendirilmesi. Unpublished Master Thesis, Ankara University, Institute of Educational Sciences.

Bloor, M. \& Wood, F. (2006). Keywords in qualitative methods: A vocabulary of Research Concepts. London: Sage.

Bora, F. D. (2013). The effect of using contextual vocabulary learning strategies on developing productive vocabulary knowledge of university preparatory class students. Unpublished Master Thesis, Gazi University, Institute of Educational Sciences.

Cengizhan, L. (2006). Üniversitelerin ingiližce hazırlı smifi ögretim programlarmm karsılastırlması. Unpublished Doctoral Thesis, Ankara University, Institute of Social Sciences.

Cesur, M. O. (2008). A model explaining and predicting the relationship between university prep class students' language learning strategies, learning styles and academic success in foreign language. Unpublished Doctoral Dissertation, Y1ldiz Technical University, Institute of Educational Sciences.

Cincioğlu, A. (2012). Instituteal factors as a component of language curriculum development: perspectives of English preparatory class lecturers at public and private universities in Istanbul. Unpublished Doctoral Thesis, İstanbul University, Institute of Educational Sciences.

Cohen, L., Manion, L. \& Morrison, K. (2005). Research methods in education. Tyler \& Francis e-Library.

Çekirdek, G. (2014). Analyzing some factors affecting preparatory class students' English achievement. Unpublished Master Thesis, Eskişehir Osmangazi University, Institute of Educational Sciences.

Çelik, S. (2015). Investigating the effect of student response system supported think-pair-share pedagogy on preparatory school efl students' vocabulary achievement. Unpublished Master Thesis, Middle East Technical University, Institute of Social Sciences.

Çetinkaya, G. (2017). The relationship among language learning strategies, motivation and academic achievement of university preparatory school students. Unpublished Master Thesis, Abant İzzet Baysal University, Institute of Educational Sciences.

Çevikbaş, H. (2016). The effect of instructional activities designed with metacognitive strategies on developing listening skills of students in university prep class. Unpublished Master Thesis, Akdeniz University, Institute of Educational Sciences.

Dağlloğlu, F. Ö. (2004). Üniversite hazırlık sinıfi ögrencilerinin yabancı dil derslerine olan tutumlarmin artırlması ve program düzenlenmesi. Unpublished Master Thesis, Yıldız Technical University, Institute of Social Sciences.

Daylan, S. (2001). A syllabus design for the basic English classes in the preparatory program at abant irzet baysal university. Unpublished Master Thesis, Abant İzzet Baysal University, Institute of Social Sciences.

Demir, Y. (2012). A comparative analysis on sofl students'perceptions regarding nest and non-nest effects on motivation and attitudes. Unpublished Master Thesis, Selçuk University, Institute of Educational Sciences.

Demirkol, T. (2009). An investigation of Turkish preparatory class students' listening comprehension problems and perceptual learning styles. Unpublished Master Thesis, Bilkent University, Institute of Educational Sciences.

Derince, Z. M. (2016). An odyssey of discovery: critical literacy in an English preparatory class. Unpublished Doctoral Thesis, Boğaziçi University, Institute of Social Sciences.

Doğan, Y. (2016). Examination of prep-class students' metacognitive awareness, self-efficacy beliefs, foreign language anxiety levels, foreign language attitudes and academic achievement in foreign language. Unpublished doctoral Thesis, Frrat University, Institute of Educational Sciences.

Efe, H. (1996). Ingilizce bölümü bąurlık sinff ögrencileri için belirli amaçh ingilizce ögretimine yönelik program gelistirme. Unpublished Doctoral Thesis, Atatürk University, Institute of Social Sciences.

Eğmir, E., Erdem, C. \& Koçyiğit, M. (2017). Trends in educational research: A content analysis of the studies published in international journal of instruction. International Journal of Instruction, 10(3), 277-294. 
Koçyiğit, M., \& Erdem, C. (2018). A content analysis of graduate research on English preparatory programs at universities. Journal of Human Sciences, 15(3), 1466-1480. doi:10.14687/ihs.v15i3.5414

Erakman, N. (2015). Student burnout in an English preparatory program at a Turkish university: a case study. Unpublished Master Thesis, Bahçeşehir University, Institute of Educational Sciences.

Erarslan, A. (2011). Perceptions and attitudes of the preparatory class students towards the writing course and attitudesuccess relationships in writing in the school of foreign languages at pamuk.kale university. Unpublished Master Thesis, Pamukkale University, Institute of Social Sciences.

Erkol, K. (2011). A study on the attitudes of canakkale onsekiz mart university prep class students' towards cooperative writing activities and effects of these activities on students success. Unpublished Master Thesis, Çanakkale Onsekiz Mart University, Institute of Social Sciences.

Ertan, A. B. (2008). Investigation of university students' motivation for learning English and their beliefs about learning it. Unpublished Master Thesis, Ankara University, Institute of Educational Sciences.

Evcim, H. (2008). Increasing vocabulary retention of university prep class students through language learning strategies. Unpublished Master Thesis, Abant İzzet Baysal University, Institute of Social Sciences.

Felek Başaran, H. (2011). The effects of captioning on efl learners' listening comprehension: an investigative study with intermediate level university prep-school students. Unpublished Master Thesis, Anadolu University, Institute of Educational Sciences.

Gülsoy, D. (2011). Opinions of English instructors and preparatory school students on the use and instruction of language learning strategies. Unpublished Master Thesis, Hacettepe University, Institute of Social Sciences.

Gültekin Çakar, G. (2009). The relationship between past language learning experiences and foreign language anxiety of Turkish university efl students. Unpublished Master Thesis, Bilkent University, Institute of Educational Sciences.

Gündüz, E. (2015). University preparatory students' perceptions towards native and non-native English speaking teachers. Unpublished Master Thesis, Çăg University, Institute of Social Sciences.

Güneş, C. (2004). Learning styles preferences of preparatory school students at gazi university. Unpublished Master Thesis, Middle East Technical University, Institute of Social Sciences.

Güntürkün, N. (2007). Using newspapers to teach vocabulary to pre-intermediate level preparatory class students. Unpublished Master Thesis, Selçuk University, Institute of Social Sciences.

Gürata, A. (2008). The grammar learning strategies employed by Turkish university preparatory school efl students. Unpublished Master Thesis, Bilkent University, Institute of Educational Sciences.

Hiçyllmaz, A. (2006). Yabanc dil olarak ingiližceyi ögrenen ortaögretim 9. sme ögrencileriyle üniversite hažrllk. smefi ögrencilerinin kullandıklar dil ögrenme stratejilerinin karşılaștırlması. Unpublished Master Thesis, Yıldız Technical University, Institute of Social Sciences.

İleri, S. A. (2013). TOBB ETÜ hažrlk smafi ögrencileirinin ödevlere karşı tutumu ve verilen ödevlerin ögrenci bassarssma etkisi. Unpublished Master Thesis, Ankara University, Institute of Social Sciences.

İnal, D., Özdemir, E., Kıray, G. \& Oral, Y. (2016). Review of doctoral research in English language teaching and learning in Turkey (2009-2013). Lang. Teach, 49(3), 390-410.

Kar, İ. (2014). An English language needs analysis of obligatory English preparatory program students at Istanbul sabahattin zaim university. Unpublished Master Thesis, İstanbul Sabahattin Zaim University, Institute of Social Sciences.

Karabey, M. (2011). Foreign language classroom anxiety of preparatory class students at Atatürk university. Unpublished Master Thesis, Atatürk University, Institute of Social Sciences.

Karabiylk, A. (2008). The relationship between culture of learning and Turkish university preparatory students' readiness for learner autonomy. Unpublished Master Thesis, Bilkent University, Institute of Educational Sciences.

Karagöl, I. (2015). To predict the speaking skills of university preparatory class students in terms of attitude towards English, anxiety and general self-efficacy. Unpublished Master Thesis, Ege University, Institute of Social Sciences.

Karakıliç, S. (2014). Evaluation of the fl coursebook "language leader" from ufuk university preparatory school students' perspectives. Unpublished Master Thesis, Ufuk University, Institute of Social Sciences.

Kaya, M. (2014). Assessment of instructor reactions to the performance management system at the preparatory program of a foundation university. Unpublished Master Thesis, Çağ University, Institute of Social Sciences.

Keşmer, E. (2007). Needs assessment of the prep-class students in the faculty of engineering at ondokurmayss university. Unpublished Master Thesis, Ondokuzmayis University, Institute of Social Sciences. 
Koçyiğit, M., \& Erdem, C. (2018). A content analysis of graduate research on English preparatory programs at universities. Journal of Human Sciences, 15(3), 1466-1480. doi:10.14687/jhs.v15i3.5414

Kilıç, S. (1992). An analysis of the relationship between students' perception and teachers' perception of major errors (tense, article, active/passive, modals, if and wish clauses, adjectives, adverbs, reported speech) experienced by the preparatory students with regard to grammar in efl at the university of Gaziantep. Unpublished Master Thesis, Gaziantep University, Institute of Social Sciences.

Koçer, T. (2012). Preparatory class students and instructors' reading strategy use in English and the examination of their approaches. Unpublished Master Thesis, Mersin University, Institute of Educational Sciences.

Korkmaz, G. (2014). Using Oxford itools and itotor software in english language teaching and its effect on preparatory class students' academic achievement. Unpublished Master Thesis, Erciyes University, Institute of Educational Sciences.

Köse, C. (2012). The evaluation of English preparatory program of Uludağ university, school of foreign languages. Unpublished Master Thesis, Uludağ University, Institute of Educational Sciences.

Mede, E. (2012). Degign and evaluation of a language preparatory program at an English medium university in an efl setting: a case study. Unpublished Doctoral Thesis, Yeditepe University, Institute of Educational Sciences.

Motha, S. (2009). Review of doctoral research in second-language teaching and learning in the United States (2006-2007). Language Teaching, 42(2), 234-255. doi:10.1017/S0261444808005648

Oğuz, M. (2017). Metacognitive reading strategy awareness of B1 level prep class students. Unpublished Master Thesis, Bahçeşehir University, Institute of Educational Sciences.

Ok, S. (2005). The analysis of English preparatory program based on the needs assessment of problem-based learning and regular groups in a foreign language-medium Institute. Unpublished Doctoral Thesis, Dokuz Eylül University, Institute of Social Sciences.

Oktay, A. (2015). Foreign language teaching: a problem in Turkish education. ProcediaSocial and Behavioral Sciences, 174, 584-593.

Önkuzu, E. (2013). The relationship between learning and thinking styles of university preparatory class efl learners and their success in L2 lexical inferencing. Unpublished Master Thesis, Gaziosmanpaşa University, Institute of Educational Sciences.

Özaydınl, B. (1994). Error analysis of preparatory class students in the use English grammatical prepositions and nonliteral phrasal verbs at the university of Gaziantep. Unpublished Master Thesis, Gaziantep University, Institute of Social Sciences.

Özdoğru, G. (2008). Teaching vocabulary through using audio jokes to pre-intermedia level preparatory class students at selçuk university. Unpublished Master Thesis, Selçuk University, Institute of Social Sciences.

Özkanal, Ü. (2009). The evaluation of English preparatory program of Eskisehir Osmangazi University foreign languages department and a model proposal. Unpublished Doctoral Dissertation, Eskisehir Osmangazi University, Institute of Educational Sciences.

Özkardeş, A. (2011). Acbievement attributions of preparatory class learners at the school of foreign languages at pamukeale university for their success or failure in learning English. Unpublished Master Thesis, Pamukkale University, Institute of Social Sciences.

Özmen, K. S., Cephe, P. T. \& Kınık, B. (2016). Trends in doctoral research on English language teaching in Turkey. Educational Sciences: Theory and Practice, 16(5), 1737-1759.

Öztürk, N. (2010). An examination of the relationship between content familiar texts derived from readers' interests and reading performance of English language learners at university level. Unpublished Master Thesis, Middle East Technical University, Institute of Social Sciences.

Padem, S. (2012). The examination of the language learning strategies of university preparatory class students with respect to various variables. Unpublished Master Thesis, Düzce University, Institute of Social Sciences.

Patton, M. Q. (2002). Qualitative research \& evaluation methods. Thousand Oaks: Sage Pub.

Pulat, B. (2010). The investigation of Z.K.U. preparatory school students' motivational level. Unpublished Master Thesis, Zonguldak Karaelmas University, Institute of Social Sciences.

Sarar, S. (2008). A comparative study of overcoming the difficulties of reading through multiple intelligence theory in english preparatory classes at school of foreign languages at selcuke university. Unpublished Master Thesis, Selçuk University, Institute of Social Sciences.

Sarıçoban, G. \& Sarıçoban, A. (2012). Atatürk and the history of foreign language education. The Journal of Language and Linguistic Studies, 8(1), 24-49. 
Koçyiğit, M., \& Erdem, C. (2018). A content analysis of graduate research on English preparatory programs at universities. Journal of Human Sciences, 15(3), 1466-1480. doi:10.14687/jhs.v15i3.5414

Selçuk, Z., Palancı, M., Kandemir, M. \& Dündar, H. (2014). Trends of studies published in journal of education and science. Education and Science, 39(173), 430-453.

Solak, E. (2014). The content analysis of the research papers on foreign language education in Turkey. International Journal of English and Education, 3(3), 167-178.

Şakrak, G. (2009). The relationship between emotional intelligence and foreign language anxiety in Turkish EFL students. Unpublished Master Thesis, Bilkent University, Institute of Educational Sciences.

Şanl, B. (2016). The factors predicting English achievement of university preparatory class students (Karabük. University Sample). Unpublished Master Thesis, Düzce University, Institute of Social Sciences.

Şen, N. (2012). Dumlupmar üniversitesi yabanc diller bölümü isteğe bağh ingiliz̨ce hažrllk programmmn öğrenci ve ögretim eleman görüslerine göre incelenmesi. Unpublished Master Thesis, Anadolu University, Institute of Educational Sciences.

Tatıs, H. (2010). An investigation into the effects of keeping journals of preparatory class instructors on teaching paragraph writing within the notion of reflective practice. Unpublished Master Thesis, Çanakkale Onsekiz Mart University, Institute of Social Sciences.

Temir, T. (2015). Relationship between using blogs and acbievement in reading skills of prep-class students at tertiary level. Unpublished Master Thesis, Hacettepe University, Institute of Educational Sciences.

Toker, O. (1999). The attitudes of teaching staff and students towards the preparatory curriculum of the department of foreign languages in the university of Gaziantep. Unpublished Master Thesis, Gaziantep University, Institute of Social Sciences.

Tokuç, C. (2014). Non-compulsory preparatory students' attitudes towards learning English. Unpublished Master Thesis, Çağ University, Institute of Social Sciences.

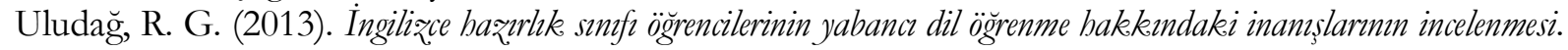
Unpublished Master Thesis, Ankara University, Institute of Social Sciences.

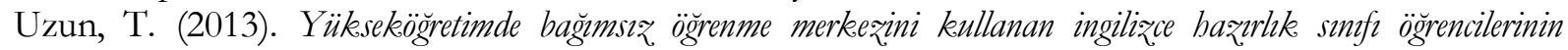
ögrenme eğilimleri ve biçemleri. Unpublished Master Thesis, Ankara University, Institute of Social Sciences.

Yağız, O., Aydın, B. \& Akdemir, A. S. (2016). ELT research in Turkey: a content analysis of selected features of published articles. Journal of Language and Linguistic Studies, 12(2), 117-134.

Yalçın, Ş. (2016). Utilizing textbook adaptation techniques in a language preparatory program: from the perspectives of novice and experienced efl teachers. Unpublished Master Thesis, Bahçeşehir University, Institute of Educational Sciences.

Y1ldız, B. (2013). Yabanc diller yükesekokulu ingilizce hažrllk smafi ögrencilerin ögrrenme ve ders çalısma yaklassimlarmm incelenmesi. Unpublished Master Thesis, Ege University, Institute of Social Sciences.

Yilmaz, F. (2004). An English language needs analysis of preparatory class students at gaziosmanpasa university. Unpublished Master Thesis, Bilkent University, Institute of Economics and Social Sciences.

Yilmaz Yakışık, B. (2012). Dynamic assessment of elt students' speaking skills. Unpublished Doctoral Thesis, Gazi University, Institute of Educational Sciences.

Yördem, A. (2016). An investigation into the prep school students' attributions for success and failure in an efl context: the case of a state university in Turkey. Unpublished Master Thesis, Çanakkale Onsekiz Mart University, Institute of Educational Sciences.

Woravut, J. (2012). A content analysis of Thai and international research articles in ELT. Doctoral Dissertation, Macquarie University, Thailand. 